\title{
A comparative analysis of the meaning of model minority among ethnic Koreans in China and the United States
}

\author{
GAO FANG \\ (Faculty of Education, University of Hong Kong) \\ Postal address: \\ Room 420, Hui Oi Chow Science Building \\ Faculty of Education, HKU \\ Pokfulam Road, Hong Kong \\ Email: gaofang@graduate.hku.hk
}

Koreans have been successful in nesting their educational achievement into places like China and the United States, where they have earned the title of "model minority". This research is a comparison of the manner in which model minority stereotype is handled by Korean Chinese and Korean Americans. The gathered data leads us to argue that ethnic Koreans in China and the US construct a multi-faceted meaning in reaction to the "model minority” stereotype. The meaning complicates the model minority stereotype through capitalizing upon a shared East Asian sense of cultural superiority to other ethnic groups while strongly emphasizing its economic marginalization and limitations. This results in valuing education as a practical means to achieve economic upward mobility or sustain ethnic culture and identity that is perceived as being unique to Koreans in the two different sociopolitical contexts. 


\section{Introduction}

Among approximately 5.7 million ethnic Koreans in the world, which is more than ten per cent of the population of South Korea, about 1.9 million - 40 per cent of all overseas Koreans reside in China, and about 1.2 million reside in the United States (Kim 2003). Among the overseas Koreans, it is the model minority stereotype that labels Korean Chinese and Korean Americans as a successful minority in the different cultural contexts (Choi 2004; Kibria 2002; Kim 2003; Lee 1996; Lew 2004, 2006; Ma 2003; Marinari 2006; McGowan and Lindgren 2006; Wong et al. 1998; Zhang and Huang 1996; Zhou 2000).

Over the last few decades, Koreans in China have been officially portrayed as a model minority with the higher level of educational, demographic, cultural, and socioeconomic accomplishments (Choi 2004; Lee 1986; Ma 2003; Zhang and Huang 1996; Zhou 2000). Like Korean Chinese, in the minds of most Americans, Korean Americans who share the racial label Asian are also perceived as a model minority who has overcome barriers to be primed for socioeconomic advancement and educational success (Kibria 2002; Lee 1996; Lew 2004, 2006; McGowan and Lindgren 2006; Wong et al. 1998; Zhou and Gatewood 2000). The model minority label suggests that ethnic Koreans in China and the US conform to the norms of society, do well in school and careers, are hard working and self-sufficient, and become a model for all minority groups, especially those minorities referred to as "backward” or "inferior". When ethnic Koreans in the two countries are included in the discourse on race or ethnicity, it is usually to talk about their "success" in comparison with African Americans, Latinos, and Native 
Americans who represent poverty and educational underachievement in the United States and those minority nationalities (shaoshu minzu) in China such as Tibetans referred to as "backward". Korean success, especially in educational attainment is attributed to their cultural predispositions with a strong work ethic and emphasis on education which are compatible with the stereotyped values of the Whites and Han Chinese (Choi 2001; Lee 1986; Suzuki 1989; Zhou 2000).

The contemporary status of ethnic Koreans as a model minority in the two countries, however, seems to be in question. Critics have increasingly considered the model minority stereotype as suspicious (Jin 2006; Kibria 2002; Lee 1996; Lew 2004, 2006; Marinari 2006; Piao 2006; Shen 2006). A few Korean Chinese scholars examined the truth of the model minority stereotype among ethnic Koreans in China and pointed out the increasing widening achievement gap among Korean students and the social and psychological costs of their academic achievement (Jin 2006; Piao 2006; Shen 2006). Some studies (Lew 2004, 2006; Marinari 2006) questioned the validity of the model minority stereotype among Korean Americans and highlighted the within-group differences in achievement. Some studies (Gao 2008; Kibria 2002; Lee 1996) scrutinized the construction of the model minority stereotype among ethnic Koreans in China and the US and pointed out the diverse and complex experiences among them and different meanings attached to the model minority label. Some others (Choi 2001; Kim 2003; Kwon 1997; Lew 2006; Min 1995) pointed out the reality of economic status among ethnic Koreans in China and the US that many Korean Chinese did not adapt well to the market economy, and many Korean Americans were in poverty. All of the mentioned 
studies challenge the cultural ecological stereotype of ethnic Koreans as a monolithic group with shared educational and socioeconomic success (Ogbu 1998; Suárez-Orozco 1991).

The success of ethnic Koreans as a model minority began to appear in China in the early 1950s and in the United States in the mid-1960s (Lee 1996; Lew 2006; Ma 1953). However, the model minority discourse evolves over time and emerges in particular ways for ethnic Koreans at the current times. Prior to the reform period in the late 1970s, it was said that Koreans have maintained their ethnic culture and managed their lives in a "cultural island" in Northeast China which isolated them from the mainstream of Han Chinese society (Choi 2001). An outcome of the "marketization” policies in China and the normalization of diplomatic relations between China and South Korea in 1992 inevitably put Korean people in various contact situations with various opportunities and challenges, therefore impacting their perspectives of the model minority (Choi 2001; Kim 2003; Kwon 1997). In the United States, the Korean community in response to the 1965 Immigration Act continues to grow in number and variety, as well as their representation in the broader cultural, economic, and political milieu typified as mainstream American society (Zhou and Gatewood 2000). The influx of Korean immigrants and American socioeconomic and geopolitical factors, have brought new challenges for the adaptation of ethnic Koreans into American society. In a pluralist country like China and the US, multiculturalism and modernization and progress coexist (Choi 2004; Lee 1986; Olivier 1993; Postiglione 1983, 2007). The comparative analysis on the response of ethnic Koreans in China and the US to local racial or ethnical regimes brings new insights into 
the issues of diversity and upward mobility under the context of globalization. This article is thus intended to scrutinize the model minority construction of contemporary ethnic Koreans in China and the United States and its implications for ethnic Korean educational aspirations. The US data relies mainly on the findings of Kibria, Lee and others, and the Chinese data relies upon Choi, Kim and newly collected ethnographic data in Northeast China. This article comparatively analyzes the history of the discourses on ethnic Koreans in the two countries, the construction of the model minority by ethnic Koreans in the contexts of their lived experience in China and the United States, and its implications for ethnic Korean educational aspirations in the two sociopolitical contexts.

\section{Discourses of exclusion and inclusion on ethnic Koreans}

Foucault’s (1980) notion of discourse draws attention to "its capillary form of existence” (p. 39). It is through the social construction of language and knowledge that discourses with the essentially formative power are seen as organizing the ways in which people think about the world and what people come to regard as appropriate, valid and true. It is clear that one discourse seems not to be unchangeable over time. The discourses on ethnic Koreans in China and the United States vary in its nature over time, and have particular meanings for ethnic Koreans at current times.

\section{“Gaoli bangzi” in prior-1949 China and “aligners" in prior-1960s US}

Korean immigration into China and the United States began in the nineteenth century. Rather, ethnic Koreans were excluded from the mainstream discourse on race or ethnicity under the control of the Qing Dynasty (1644-1911) or of the Nationalist Party's Republic 
of China (1911-1949) in China and under the stereotyped racial regimes in the US (Lee 1996; Olivier 1993).

The Qing government in 1881 opened the northeast to settlement by Korean immigrants mainly to counter the increasing influence of Czarist Russia and Japan (Kim 2003; Lee 1986; Mackerras 1994; Piao 1990). The early Qing government did not view Koreans as legitimate residents (Piao 1990). The late Qing government, however, in 1909 signed the Sino-Japanese Agreement with the recognition of the "residence of Korean subjects” in Northeast China in order to prevent Japan from using the presence of Koreans in China as one excuse for its penetration into Manchuria (Lee 1986). After 1911 the Republican government categorized the total population into "five races" including the Han, Manchus, Mongols, Tibetans, and Moslems (Hansen 1999). The Koreans were treated as "migrants" and were not officially recognized their legitimate residence in Northeast China (Olivier 1993). With the growing Japanese penetration into Manchuria from 1910 through 1930s, Koreans were involved in the Japanese regime's policy-induced immigration into Manchuria. They were caught in a larger political contest between China and Japan. Koreans were viewed by the Zhang Zuolin warlord government as "the vanguard of the Japanese invasion" and called "gaoli bangzi" in a pejorative sense (Lee 1986).

Although ethnic Koreans have been on the mainland of the United States for more than one century, their voices are neglected in the mainstream discourse on race, which is generally framed among Blacks and Whites (Lee 1996). Asians including ethnic Koreans 
in the United States had often been stereotyped as uncivilized and unassimilable foreigners in negative ways. The first group of Korean immigrants into the United States in 1903 worked on Hawaiian sugar plantations (Zhou and Kim 2006). Between 1904 and 1907, approximately one thousand Koreans entered the mainland from Hawaii in order to escape from the difficult working conditions on the plantations. On the mainland, however, they experienced the same kinds of discrimination that other Asian groups encountered. The kinds of discrimination included being prohibited from attending school with Whites in San Francisco, being unable to intermarry with Whites (California Anti-Miscegenation Law 1901) and being unable to own land in California (1913 Alien Land Law).

\section{Discourse of model minority on ethnic Koreans in China and the US}

The official discourse that chronicled the success of ethnic Koreans as a model minority in China began to appear as early as in 1951. In November 1951, Minister of Education Ma Xulun singled the Korean out as an outstanding model for minority education (Ma 1953). A front-page article in China’s People’s Daily (Renmin Ribao August 27, 1983) praised the Korean people in Yanbian for their laudable tradition of valuing education and their exceptional educational achievements as a stimulus for China's four-modernization campaign (Lee 1986). The Korean minority is widely believed to have the highest level of college attendance and lowest level of illiteracy rates (Ma 2003). According to Ma (2003), Korean illiteracy rate is 3.3 per cent of the population, whereas the national average is 9.5 per cent. While attendance in higher education among Koreans is the highest with 8.6 per cent, the national average is 3.8 per cent. The heart of Korean achievements is, it is said, their cultural predispositions, which attach a high priority to 
the value of education (Choi 2001; Lee 1986). The cultural explanations are also associated with Korean extraordinary achievements in birth control, income, political and cultural activities (Choi 2001; Kim 2003; Lee 1986; Ma 2003; Zhou 2000).

Unlike the model minority stereotype among ethnic Koreans in China which is state-sponsored, the stereotype is entitled to Asians including ethnic Koreans in the US through the process of botterm-up as a popular image in the public press/media. The success of Asian Americans began to appear in the popular press in the mid-1960s (Lee 1996). In January 1966, New York Times Magazine contained "success literature" upon Japanese Americans and highlighted the discrimination Japanese Americans experienced and their efforts and determination to succeed. In December 1966, U.S. News \& World Report published an article lauding the success of Chinese Americans. Chinese Americans were singled out as a model minority. They were believed to be quiet and hardworking, and achieved success without the help from the government. During the 1980s and 1990s the model minority stereotype reached beyond Chinese and Japanese Americans to include Southeast Asians as a whole (Lee 1996). It was in the 1992 riots that the model minority stereotype was once again paraded across the popular press with the focus on Korean Americans (Chow 2003; Lee 1996). Korean Americans were described as hardworking, self-made immigrants and the frontline forces of the White bourgeoisie. The stereotype lumps Asian Americans together as a homogeneous group with economic and educational success (Brand 1987; Espiritu 1992; Lee 1996; Osajima 1988). Asian Americans are believed to not only attend college at a high rate, but also in the aggregate, be more likely than Whites, Blacks, or Hispanics to have higher GPAs, math SAT scores, and 
college-graduation rates (Hsia 1988; Kao and Tienda 1998; McGowan and Lindgren 2006; Sue and Okazaki 1990). The popular press in the 1980s began to recognize the potential negative implications of the model minority stereotype. Yet, Asian Americans have continued to be described as the successful minorities who have assimilated into mainstream American life through individual effort (Osajima 1988).

The model minority stereotype was not created by ethnic Koreans in China and the US themselves but was thrust upon them in the form of the official or popular discourse. But its political, economic and cultural value, to a large extent, supports the existence of the stereotype (Apple and Weis 1983; Lee 1986). For ethnic Koreans in China, Korean political and economic value and contributions of ethnic Koreans to the Chinese Communist Party (CCP) both prior to and after China's reform period are part of the reason for the designation of "Korean nationality" (chaoxian zu) as a model minority (Kim 2003; Piao 1990). Politically, (1) ethnic Koreans’ concentrated regions, especially the Yanbian Korean Autonomous Prefecture has the strategic importance in adjoining the politically sensitive Korean Peninsula and Russia (Kim 2003); (2) ethnic Koreans joined the united front with Han people, and played a vital role in the liberation of Manchuria, the civil war (1946-1949) and the Korean War (the "Resist-America and Aid-Korea" campaign) (Choi 2001; Kim 2003; Lee 1986); (3) the increasing contacts with the Koreans in the Peninsula in China's reform period involve the fugitives from North Korea (Choi 2001) and the potentially political link with the South Korean government or several nationalistic groups in South Korea (Kim 2003). The contacts draw large attention from the government. Economically, (1) ethnic Koreans were the pioneers in constructing 
and developing the northeastern frontier by cultivating rice paddies (Choi 2001; Cui 1990; Piao 1990); (2) much of the territory ethnic Koreans occupy contains China's richest mineral and timber deposits and most productive meat and wool raising areas, which are thus of great interest to the CCP government; (3) the increasing contacts with North and South Koreans in China's reform period promote border trade between China and North Korea and South Korean direct investment in China with ethnic Koreans as the middle-men, due to ethnic and linguistic ties (Choi 2001; Kim 2003; Ma 2004). The government thus continuously labels the Yanbian Korean Autonomous Prefecture as the model of "national integration and progress" to highlight the success of ethnic Koreans and their loyalty to the CCP (Kim 2003).

Likewise, the political and cultural value of the model minority stereotype among Asians in the US has never been ignored. The model minority stereotype emerged in the civil rights era with increasing charges of racial injustices being made by African Americans and other minorities such as the Watts riots (Lee 1996; Osajima 1988; Suzuki 1977). According to Lee (1996), the model minority stereotype was to divert attention away from the social reality of racial inequality. It was popularized by the press as a hegemonic device to help maintaining the dominance of Whites in the racial hierarchy of American society, and silence the challenge of other minorities to the existing system. The title of "model minority" implied that other minority groups should model the behavior of Asian Americans rather than protest inequality. The model minority stereotype has been used to emphasize the ideologies of meritocracy and individualism claiming success and upward mobility is possible through hard work. Ogbu's (1998) 
cultural ecological model distinguishes between voluntary and involuntary minorities. Voluntary minorities such as Asian Americans including Korean Americans are defined as immigrants who voluntarily come to the US in search of a better life. Involuntary minorities such as African Americans are defined as those who have been incorporated into the US through slavery or conquest. According to the cultural ecologists (Ogbu 1998; Suárez-Orozco 1991), voluntary minorities are more likely to succeed educationally because they view education as a means for success and upward mobility. But involuntary minorities underachieve in schooling which is seen as opposite to their culture and identities and do not believe the possibility of social mobility. The cultural ecological theory attributes the success and failure of minority groups in the US to their cultural values (Ogbu 1998; Suárez-Orozco 1991), which lead the "culture of poverty" ethnic minorities to be blamed for their failure.

\section{Data for ethnic Koreans' construction of the model minority stereotype}

There is a shortage of empirical studies on the construction of ethnic Koreans as a model minority in the two countries. Kibria's (2002) interpretations, which were, to some extent, compatible with this ethnographic research on ethnic Koreans in China were thus adopted in the comparative analysis of the model minority stereotype. Kibria's (2002) research was focused on the issues of identity construction, with attention given to the construction of the model minority stereotype. The research looked at race and identity in the lives of second-generation Chinese and Korean Americans. Kibria (2002) conducted in-depth interviews with 64 participants, over a span of about five years, from 1992 to 1997. Of the 64 participants, 33 were Korean American. Each interview lasted from one 
and a half to four hours focused on the racial and ethnic experiences of participants. The 33 Korean Americans were the adult children of Korean immigrants, between the ages of 21 and 40. They had been born or raised in the United States since the age of 12 or younger. Interviewees were mainly from Los Angeles informally dubbed as "the Korean capital of the United States” and the Boston area. However, many of them were not originally from either city but had grown up in other parts of the United States. Roughly many had moved to these areas for school- or work-related purposes, suggesting an experience of upward socioeconomic mobility. The group of informants was largely middle-class and college-educated. The Immigration Act in 1965 which abolished the quota system that had restricted the number of Asians allowed to enter the United States led large numbers of Koreans to the US. Post-1965 Korean immigrants are mainly composed of largely urban, well-educated and professional immigrants (Lew 2006; Portes and Rumbaut 1996; Zhou and Kim 2006). A high proportion of participants in Kibria’s (2002) study worked in professional occupations, whereas those involved in small business and unskilled service jobs were relatively absent.

This ethnographic research conducted in Northeast China interviewed twenty-seven Korean families whose children, during the 2006-07 school year when this study was undertaken, were participating in two fourth-grade classes in a twelve-year bilingual Korean school in Liaoning Province (one northeastern province). From September 2006 through January 2007, family interview took place in their homes. Each family was interviewed once time and the length of each family interview ranged from one to two hours. Fathers, mothers, and grandparents participated in interviews even though the 
family member who attended the parents' evening and filled out the screening survey was the primary informant in all families. The parents among these families were fourth-generation indigenous Korean Chinese, between the ages of 30 and 50, who had been born and grew up in Northeast China. According to the screening survey, twenty-three of the families (85 per cent) were involved in intra-China and international mobility in the search for job opportunities and were employed in the manual labour sector. Out of the twenty-three Korean families, twenty-two families had at least one member working in South Korea. The remaining four Korean families either were economically inactive and unemployed or ran small businesses. In terms of socioeconomic background, the great majority of the Korean families, especially those which were involved into foreign labour earned a relatively higher income. Rather, according to the informants, the instability of international labouring employment and their non-involvement in the mainstream economy have influenced the safety or stability of family financial status. Each interview was audio-taped and all tapes were transcribed. All of the Korean families practiced a mixture of Korean and Mandarin. Each interview was conducted in Mandarin and translation into English involved the interpretative translation through making sense of the meanings that the interviewees conveyed. Interviews were supplemented by informal, natural conversations with the Korean informants involved. By giving ethnic Koreans a voice, it was a new experience for the researcher to be on the receiving end of the power differential between majority and minority, and to focus on ethnic Koreans' subjective experiences.

\section{Ethnic Korean construction of the model minority stereotype}


The model minority stereotype seems positive and even flattering when compared with the stereotypes of other "culture of poverty" or "backward" minorities (Lee 1996; Olivier 1993). Rather, the Korean Chinese and Korean Americans define it in particular ways which attach very different meanings to the model minority label (Gao 2008; Kibria 2002). The model minority stereotype, for the ethnic Koreans in China and the US, carried with them a highly multidimensional set of meanings as a basis for asserting what they were, and what they were not. At some times, the stereotype was a matter of cultural affirmation and superiority. At other times, it was a focus not of affirmation, but of resistance against the economic marginalization and barriers to moving up in the mainstream economy.

\section{Cultural superiority}

Koreans, the stereotype infers, have a cultural orientation or work ethic that makes them able and likely to succeed (Choi 2001; Lee 1986; Suzuki 1989; Zhou 2000). For the Korean Chinese informants, the Korean is "an excellent nationality (minzu)". These core "values" were an emphasis on etiquette, solidarity, cooperation, diligence, and respect for authority. One Korean informant defined what was basic to the Korean culture:

There are certain things that I think stick with us, that work for us, and one of them is the view of the importance of family and education, you know, being respectful to older people, being a good student, and so on and so forth.

For the Korean Americans, the model minority stereotype was also a source of ideas 
about the shared culture and worldview of Asian Americans. The basic message was rooted in their notions of success and merit:

There's no doubt in my mind, that Asians have an edge at work because of the values they're raised with. My parents left no doubt in my mind that you had to work hard, there were no excuses [Quoted in Kibria $(2002,148)]$.

Reflecting the fundamental character of model minority, this process of definition involved constant comparison, both implicit and explicit, of Koreans to other ethnic groups. Some minority groups such as Tibetans or African Americans have always posed challenges to the central government of the PRC and the dominance of Whites. In comparison, ethnic Koreans in China and the US hardly cause any form of unrest (Lee 1986; Mackerras 1994; Ogbu 1998; Olivier 1993; Zhou 2000). When the subject turned to governmental policy for minorities, preferential policy or affirmative action in particular, the Korean informants in contrast to other minority groups were more willing to speak of who specifically did not have the core values of work and self-sufficiency. Indeed, preferential policy or affirmative action as a topic especially reflected the inter-minority comparison. The model minority stereotype seemingly created a distinction, in the consciousness of Korean Chinese informants, between the good, model minority and the "backward" minority. Many of them felt a certain distance between Koreans and preferential policy, largely because of the Korean cultural values of self-sufficiency and belief in merit, which clashed with a system of preferences. One informant remarked: 
I think that in general our culture discourages us from taking handouts, and that we need to be proud and accomplish things on our own. I guess what I'm saying is, I'm not sure Koreans in particular need it. It's a good thing, definitely. But we ever succeeded without any preferential policy in the past, didn’t we? I think we just want to do it on our own.

Likewise, the Korean American informants in Kibria’s (2002) study asserted that Asians did not actually need the affirmative action to succeed. They felt profound uncertainty about the affirmative action. The issue of affirmative action seemed to provide them a forum to affirm the Asian cultural values, in contrast to the values of other minorities:

I don't think affirmative action is really an Asian issue. I think in most places Asians don't have the official minority status - they're not an underrepresented minority. It's something that has more to do with Blacks and Hispanics [Quoted in Kibria (2002, 156)].

Deeply intertwined with the informants' comments on cultural qualities were reflections on how these qualities made them similar to or different from Han Chinese and Whites. As the Korean Chinese informants highlighted the cultural characteristics of ethnic Koreans, they frequently mentioned Han Chinese. Han Chinese, they often claimed, were similar to Koreans in their emphasis on work, education, family, self-sufficiency, and enterprise. However, while the Korean Chinese informants made 
comparisons between Korean values and the values of Han Chinese, in some cases the comparisons were points of contrast rather than similarity. The discourse on "corruption and declining morality" underlied their construction of this contrast. The Korean informants painted a picture of Korean Chinese community as being morally superior in comparison to the mainstream of Han Chinese society:

I was raised with certain Korean values, like discipline, respect, honesty. I do feel like those are parts of Korean culture that are important, that I'd like to keep. I think that they're lacking in many Han Chinese.

For the Korean Americans, the political discourse on "declining family values" in the United States also provided an important point of reference in their construction of the contrast between Asian values and the values of American society. According to one informant:

Asians do have the advantage in the workplace of having been raised to value working hard and being disciplined in your work. Americans have that problem, they don't have the same attitude [Quoted in Kibria $(2002,150)]$.

The process of responding to the model minority stereotype positioned ethnic Koreans within the social landscape of China and the US. There was no doubt that the dominant groups and other minorities provided the contrastive backdrop for Korean assertion of their identity: Korean Chinese or Korean Americans with a strong or clear 
sense of ethnic roots were not the unhyphenated Chinese or Americans (Gao 2008; Kibria 2002). It was these connotations - of morality, hard work, and self-sufficiency in Korean informants' affirmations that ethnic Koreans were not simply Chinese or Americans, but Korean Chinese - "Chinese citizens and a Korean nation” or ethnic Americans.

\section{Economic marginalization and limitation for upward mobility}

The model minority stereotype suggests that ethnic Koreans in China and the US are more successful both culturally and economically. But the Korean Chinese and Korean Americans evidently came to terms with the cultural accomplishments rather than economic success and upward mobility. China's economic reforms and open door policy cause an awareness of being marginalized economically in Korean collective consciousness (Choi 2001; Kim 2003). The primarily agricultural-based Korean economy has lost its edge in the reform period and led to a mass exodus of ethnic Koreans mainly toward large urban areas in the search of job opportunities (Kim 2003). A great majority of the Korean Chinese informants came to see themselves as less involved in the mainstream economic society. Korean community, especially Yanbian, was regarded by the informants as "a geo-economic hinterland" in comparison with the coastal areas. A Korean informant running a small restaurant remarked:

I have the potential to manage business like a small restaurant. But we seem not to enter the mainstream business circle. Koreans, like some of my friends, are engaged mostly in a career connected with Korean companies rather than a much more rewarding career in mainstream Chinese society...We are unable to compete in the 
marketplace with them [Han Chinese].

Koreans are less competitive and less connected in business than the Han Chinese with their superior Chinese skills (Kim 2003). The high level of education has been achieved by Korean Chinese through Chinese and Korean bilingual education, with an emphasis on Korean language as the medium of instruction from national elementary to high school (Ma 2004; Zhou 2000). Rather, the Korean language seems not to help for the success and upward economic mobility of Koreans in Chinese society (Kwon 1997). It was frequently heard from the informants that: "We cannot compete with Han Chinese and their superior Chinese skills. Koreans are at the periphery of the Chinese economy.”

The negative remarks on economic involvement into the mainstream were also associated with labour export to South Korea. For the Korean Chinese informants, however, a higher status career was not associated with labour export in South Korea. An informant told me about her mother's conversation with her son:

She asks him, what is your destiny? Do you want to be a manager or factory worker? You must study harder and harder, otherwise, you would be like your parents who are not able to find jobs except for labouring jobs in South Korea.

Korean Chinese are engaged mostly in “3-D” - dirty, difficult, and dangerous jobs in South Korea (Kim 2003), which make working in South Korea less desiring for the informants to consider about career. The globalizing South Korean economy demands 
more professionals who can command English. Recognizing the strategic value of overseas Koreans, the DJ Kim government in South Korea promulgated a special law in 2000 regarding overseas Koreans with a larger goal to create a global Korean community (Shin 2002). However, in practice, the main target of this special law is Korean Americans. Koreans in China and Russia are more or less excluded in the law because the South Korean government is afraid to open the door to unskilled Koreans from these countries (Shin 2002). Korean Chinese earn an income almost ten times higher than they would earn in China. However, they are often treated by their employers unfairly and delegated to the lower strata of South Korean society as illegal immigrants (Kim 2003).

For the Korean Americans, the model minority stereotype not only applauded their achievement, but also worked to limit its scope (Kibria 2002). While Asian students are described as "good but limited" students, the limitations of Asian achievement also find expression in Asian Americans in their occupational choice (Kibria 2002; Wing 2007). Asian Americans were focused on the technical and scientific fields. Sue and Okazaki's (1990) concept of relative functionalism considers the overwhelming concentration of Asian students on the mathematics, sciences and engineering fields as the adaptive response toward the host society. What was expected of an Asian thus acted to close certain occupations and fields of specialization and redirected Asian Americans in their career choices. As a Korean American informant commented:

I didn't do the typical Asian thing, not computers, not law school, not an MBA. It’s been difficult because of the expectations. It's what Asians are supposed to do, and a 
lot of them do. But I have to do what I believe in, draw on my talents. I'm a very extroverted, talkative, unconventional kind of person. It's a stereotype, of course, that Asians are not like that. It frustrates me that we get boxed in [Quoted in Kibria (2002, 139)].

Among the limitations, is one suggestion that Asians have a passive, introverted personality style, which makes them unsuited for positions of leadership. The passivity is associated with the expression in the "glass ceiling" - the inability to penetrate the uppermost tiers of the business ladder (Der 1993; Kibria 2002; Ong and Blumenberg 1994; Tang 1993; Woo 2000). With a quiet and routine personality among Asian Americans, the model minority stereotype presumes the dynamics of the glass ceiling for Asians by marking them as "not leadership material" (Kibria 2002). Among the Korean Americans in Kibria's (2002) study, this presumed passivity was a particularly important point for their rejection of the model minority stereotype. According to one informant:

I'm kind of obstinate. I want to know, what does it take to get to the very top in corporate America? There's the glass ceiling - you probably have heard about that... Then there's the whole idea of Asians being book-smart but not politically savvy, and hardworking but not aggressive. Asians are not viewed as leadership material... [Quoted in Kibria $(2002,140)]$.

The stereotype's implication of passivity was seen by Kibria's informants as one barrier faced by Asians to moving up in the mainstream economy. The informants 
considered the glass ceiling as accompanied by a form of racism unfairly imposed upon Asian Americans. As one informant remarked:

I only became aware of racism when I started working. You're so protected in a college environment. But with work, you start seeing all the subtle ways in which being Asian does matter, like the glass ceiling...[Quoted in Kibria (2002, 146-7)].

\section{Ethnic Korean education aspirations in China and the US}

The accounts of the informants in China and the US were largely focused on cultural and economic issues. The cultural superiority and economic marginalization and limitations have large implications for high educational aspirations among ethnic Koreans regardless of their socioeconomic status and educational level (Gao 2008; Lee 1986; Lew 2004, 2006; Park 1998). However, their high educational aspirations involve the different meanings in the different sociopolitical and cultural contexts.

Korean settlement in the Unites States is different from the case of many European immigrants to the US, in which there seems no major conflict rooted in racial differences between the dominant group and the minority group. Asian Americans have long been seen as immigrants and unassimilable foreigners as opposed to American minorities (Ogbu 1991). The image is derived from the Orientalist discourse emphasizing that there are innate differences between the East and the West and Asians could never become Americans (Cheung 1993; Said 1979). Among the post-1965 ethnic Koreans entering the United States mostly from South Korea or from the North coming via South Korea, their 
shared language and ethnicity explain the formation of strong ethnic network throughout the United States and the positive willing to maintain ethnic culture and identity while participating into the mainstream society (Lew 2006; Min 1995, 1996). For them, the constant discrimination they encounter in the daily life only implies that schooling is the only avenue available for mobility and integrating into the mainstream American society (Sue and Okazaki 1990). According to Wing (2007), the emphasis on education is socially necessitated because other avenues for upward mobility such as leadership and politics have been closed to Asians. This is caused by the mainstream views on their apoliticality and shortage of human qualities such as leadership or intolerance toward oppression. The model minority image with its emphasis on education causes many Asians in the US to develop "an almost desperate faith in schooling” (Suzuki 1977, 44) for their children's future.

Koreans' settlement in China, in contrast, is relatively easy, which can mainly be attributed to China's minority policy (Lee 1986). The Korean is one of China's fifty-five officially recognized minority nationalities. Despite their foreign origins, according to Olivier (1993), ethnic Koreans in China have managed a peaceful cohabitation with the Han people and successfully adopted themselves to China's socialist regime. In the Yanbian Korean Autonomous Prefecture, which contains more than 40 per cent of the total Korean population in China, ethnic Koreans exercise regional autonomy aiming to foster political integration with cultural diversification in recognition of one state with many nationalities (Postiglione 2000). For ethnic Koreans in China, China’s economic reforms and open door policy are creating new challenges to them. Koreans seek to 
survive as a distinct ethnic group without completely being assimilated into the mainstream society, while increasing competitiveness in the job market and upward social mobility through education. The new market economy needs minority graduates with competency in Chinese language skills. This ironically drives ethnic minorities to acculturate into the mainstream language and lead to the loss of ethnic cultural or linguistic capital (Olivier 1993). The traditional Korean communities become too disintegrated to maintain Korean identity and culture due to the increasing mobility of population (Kim 2003). Some Koreans are opting for a conscious and deeper cultural integration into mainstream Han society under the economic liberalization and market prosperity (Olivier 1993). The "Koreanness" of their identity is never threatened by any overt discrimination at a collective level (except during the course of the Cultural Revolution 1966-1976). However, schooling becomes necessary for Korean children to strive for the maintenance of ethnic identity in China's reform period.

\section{Conclusion - Multiculturalism and upward mobility in globalization}

Ethnic Koreans are still one group in China and the US with the higher level of educational and socioeconomic accomplishments. Rather, studies (Gao 2008; Jin 2006; Kibria 2002; Lee 1996; Lew 2004, 2006; Marinari 2006; Piao 2006; Shen 2006) have shown that the previous solo voice among ethnic Koreans as a model minority is gradually being replaced by a complicated voice of Korean achievement and attainment. The Korean Chinese informants in Gao's (2008) study spoke of the model minority stereotype as a source of ideas about their cultural superiority and dual economic marginalization in the Chinese and South Korean mainstream societies. In Kibria’s (2002) 
study, the Korean American informants internalized the Asian cultural superiority in affirmative ways. But they were struggling to resist the potential limits and dangers of the model minority label in their academic and economic career.

Quite clearly, there is the increasing heterogeneity among ethnic Koreans in class, educational level, immigration history, and adaptation style. The discourse on "model minority” does not come to inform each sense of self that Korean Chinese and Korean Americans adopt. While the lack of original data on Koreans in the US might weaken the analysis, the shortage has largely been compensated with a richness of data on the historical and current status of ethnic Koreans in China and the US. In both of the cases, the process of responding to the model minority stereotype was intertwined with the activity of positioning: of locating ethnic Koreans within the social hierarchy of China and the US. On the one hand, it was these connotations - of morality, hard work, and self-sufficiency in ethnic Korean informants' affirmations that ethnic Koreans, in particular by their culture, were not simply Chinese and American, but Korean Chinese and Korean Americans. On the other hand, ethnic Koreans in China and the US, by their economic and social status, were racial "otherness" in the Chinese and American mainstream societies. With the complexity and variation among ethnic Koreans in the two countries in terms of academic achievement, socioeconomic status, and meaning construction out of the model minority stereotype, the comparative analysis complicates the model minority stereotype. The stereotype tends to essentialize ethnic Koreans as a group with shared attitude toward schooling and educational and economic success. Koreans as a whole still keep the relatively higher level of academic and economic 
accomplishments in the two countries. Rather, the simplified model minority stereotype may serve to reinforce the cultural explanations for ethnic Koreans, and silence the disadvantages suffered by them in China and the US.

This growing assertiveness on the part of ethnic minorities with growing access to resources of social and cultural capital moves the nature of ethnicity in China and the US from American cultural pluralism or pluralism within the Chinese nationality to a "critical pluralism”. It is driven by rising saliency of ethnicity within globalization. Within each society's context of ethnicity such as the US’s “cultural pluralism” and China’s “duoyuan yiti geju" (Fei 1991) which has been translated by Postiglione into "plurality within the organic unity of the Chinese nationality”, ethnic groups are assigned attributes that adhere to the popular perceptions of their ethnic identities. These assigned attributes, such as model minority in the case of ethnic Koreans in China and the US, shape ethnicity, especially in the early phase of national integration measures through schooling. Ethnic groups whether as indigenous ethnics or migrant ethnics, with the increasing economic and social capital resources over time actively respond to the assigned attributes by reconstructing the attributes of their own ethnic identity. In the case of ethnic Koreans, perhaps more than other minorities, their intellectual capital within educational institutions is used to reassert a more accurate portrayal of the complexities of their ethnicity within the national, and increasingly, global framework. 


\section{Notes}

1. Preferential policy (youhui zhengce) in minority regions consists of child birth, employment, taxation, infrastructure development preferential treatment for minority nationalities, and subsides for minority education and special educational opportunities (for example, taking portions of the examination in their native language, access to higher education with lower entrance marks, and first consideration for enrolment) (Postiglione 1995; Sautman 1998).

2. Affirmative action has been defined by The Civil Rights Commission as “encompassing any measure, beyond the simple termination of a discriminatory practice, which permits the consideration of race, national origin, sex or disability, along with other criteria, and which is adopted to provide opportunities to a class of qualified individuals who have either historically or actually been defined these opportunities, and to prevent the recurrence of discrimination in the future” (Curry 1996). It includes the enforcement of fair employment practices, government programs regarding the awarding of federal contracts and licenses, and civil rights laws.

3. The Law on Regional Ethnic Autonomy was adopted in May 31, 1984 at the second session of the Sixth National People's Congress. Regional autonomy means that under the unified leadership of the state, autonomy can be practiced in areas where minority nationalities live in concentrated communities (Postiglione 1992). In these areas organs of established self-government can have increased local control over the administration of resources, taxes, birth planning, education, legal jurisdiction and religious expression 
(Gladney 1994).

\section{Notes on contributor}

Dr. GAO Fang graduated from Ph.D. program in Education at the University of Hong Kong. Prior to that, she got M.A. in Educational Sciences at the University of Amsterdam. Her research examines the schooling experiences of Korean students behind the model minority stereotype.

\section{References}

Apple, Michael W., and Weis, Lois. 1983. "Ideology and practice in schooling: A political and conceptual introduction.” In Ideology and practice in schooling, eds. M. W. Apple and L. Weis. Philadelphia: Temple University Press.

Brand, David. 1987. "The new whiz kids.” Time 130(9): 42-51.

Cheung, Kok. 1993. Articulate silences: Hisaye Yamamoto, Maxine Hong Kingston, Joy Kogawa. Ithaca, NY: Cornell University Press.

Choi, Sheena. 2004. "Citizenship, education, and identity: A comparative study of ethnic Chinese in Korea and ethnic Koreans in China." International Journal of Educational Reform 13(3): 253-266.

Choi, Woo-Gil. 2001. "The Korean minority in China: The change of its identity." DEVELOPMENT AND SOCIETY 30: 119-141.

Chow, May. 2003. Korean American history. AsianWeek. http://www.asianweek.com/2003_01_10/feature_timeline.html.

Curry, George E. ed. 1996. The affirmative action debate. Reading, Mass: 
Addison-Wesley.

Der, Henry. 1993. Affirmative action policy. The State of Asian Pacific America: Policy Issues to the Year 2020. Los Angeles: LEAP Asian Pacific American Public Policy Institute and UCLA Asian American Studies Centre.

Espiritu, Yen Le. 1992. Asian American panethnicity: Bridging institutions and identities. Philadelphia: Temple University Press.

Fei, Xiao Tong. 1991. Zhonghua minzu yanjiu xin tance [New Explorations in China’s Ethnic Studies]. Beijing: Chinese Academy of Social Sciences Publishing House.

Gao, Fang. 2008. "What it means to be a "model minority": Voices of ethnic Koreans in Northeast China.” Asian Ethnicity 9(1): 55-67.

Gladney, Dru C. 1994. “Representing nationality in China: Refiguring majority/minority identities.” The Journal of Asian Studies 53(1): 92-123.

Hansen, Mette Halskov. 1999. Lessons in being Chinese: Minority education and ethnic identity in southwest China. Seattle: University of Washington Press.

Hsia, Jayjia. 1988. Asian Americans in higher education and at work. Hillsdale, NJ: Erlbaum.

Iredale, Robyn., et al. 2001. Contemporary minority migration, education and ethnicity in China. Cheltenham, UK: Edward Elgar.

Jin, Ming Shu. 2006. Chaoxianzuzhongxiaoxuedanqin, wuqinjiatingxuesheng jiaoyuchutan [The preliminary discussion about schooling for danqin and wuqin Korean students]. Paper presented at the Korean Chinese Education Forum (1906-2006), Yanbian University, China.

Kao, Grace, and Tienda, Marta. 1998. “Educational aspirations of minority youth.” 
American Journal of Education 106: 349-384.

Kibria, Nazli. 2002. Becoming Asian American: Second-generation Chinese and Korean American identities. Baltimore: The Johns Hopkins University Press.

Kim, Ill. 1981. New urban immigrants: The Korean community in New York. Princeton, NJ: Princeton University Press.

Kim, Si-joong. 2003. “The economic status and role of ethnic Koreans in China.” In The Korean diaspora in the world economy, eds. C. F. Bergsten and I. Choi. Washington, DC: Institute for International Economics.

Kwon, Tai Hwan. 1997. "International migration of Koreans and the Korean community in China.” Korea Journal of population and development 26(1): 1-18.

Lee, Chae-Jin. 1986. China's Korean minority: The politics of ethnic education. Boulder: Westview Press.

Lee, Robert. 1999. Orientals: Asian Americans in popular culture. Philadelphia: Temple University Press.

Lee, Stacey J. 1996. Unraveling the "model minority" stereotype: Listening to Asian American youth. New York: Teachers College, Columbia University.

Lew, Jamie. 2004. “The “other” story of model minorities: Korean American high school dropouts in an urban context." Anthropology and Education Quarterly 35(3): 303-323.

Lew, Jamie. 2006. Asian Americans in class: Charting the achievement gap among Korean American youth. New York: Teachers College Press.

Ma, Chun Hua. 2004. "Language practice and identity of Korean-Chinese bilinguals in Yanji.” PhD diss., Michigan State University. 
Ma, Rong. 2003. “Zhongguogezuqunzhijiande jiegouxingchayi [The structural disparities between China’s ethnic groups].” Shehui kexue zhanxian 4: 174-185.

Ma, Xu Lun. 1953. Minzu zhengce wenxian huibian [Collections of China's minority policy]. Beijing: Renmin chubanshe.

Mackerras, Colin. 1994. China's minorities: Integration and modernization in the twentieth century. Hong Kong: Oxford University Press.

Marinari, Melissa. 2006. "Racial formation and success among Korean high school students.” The Urban Review 37(5): 375-398.

McGowan, Miranda Oshige, and Lindgren, James. 2006. "Testing the "model minority myth”.” Northwestern University Law Review 100(1): 331-378.

Min, Pyong Gap. 1995. Asian Americans: Contemporary trends and issues. Thousand Oaks, CA: Sage Publications.

Min, Pyong Gap. 1996. Caught in the middle: Korean communities in New York. Berkeley: University of California Press.

NBSC. 2005. China statistical yearbook. Beijing: China Statistical Press.

Ogbu, John U. 1991. "Immigrant and involuntary minorities in comparative perspective.” In Minority status and schooling: A comparative study of immigrant and involuntary minorities, eds. M. Gibson and J. U. Ogbu. New York: Garland.

Ogbu, John U. 1998. "Voluntary and involuntary minorities: A cultural ecological theory of school performance with some implications for education.” Anthropology and Education Quarterly 29(2): 155-188.

Olivier, Bernard Vincent. 1993. The implementation of China's nationality policy in the northeastern provinces. San Francisco: Mellen Research University Press. 
Ong, Paul, and Blumenberg, Evelyn. 1994. Scientists and engineers. The State of Asian Pacific America, a Public Policy Report: Policy Issues to the Year 2020, 165-92. Los Angeles: LEAP Asian Pacific American Public Policy Institute and UCLA Asian American Studies Center.

Osajima, Keith. 1988. "Asian Americans as the model minority: An analysis of the popular press image in the 1960s and 1980s." In Reflections on shattered windows: Promises and prospects for Asian American studies, eds. G. Y. Okihiro, S. Hune, A. A. Hansen, and J. M. Liu. Pullman: Washington State University Press.

Park, Clara C. 1998. "Educational and occupational aspirations of Korean youth in Los Angeles.” In Current issues in Asian and Pacific-American American education, eds. R. Endo, C. C. Park, and J. N. Tsuchida. California: Pacific Asia Press.

Piao, Chang Yu. 1990. "The history of Koreans in China and the Yanbian Korean Autonomous Prefecture.” In Koreans in China, eds. D. S. Suh and E. J. Shultz. Hawaii: The Center for Korean Studies, University of Hawaii.

Piao, Jing Yu. 2006. Minzuxuexiaodanqin, wuqinxueshengdejiaoyuchutan, [The preliminary discussion about schooling for danqin and wuqin Korean students in national schools]. Paper presented at the Korean Chinese Education Forum (1906-2006), Yanbian University, China.

Portes, Alejandro, and Rumbaut, Ruben G. 1996. Immigrant America: A portrait. Berkeley: University of California Press.

Postiglione, Gerard A. 1983. Ethnicity and American Social theory: Toward Critical Pluralism. Lanham: University Press of America.

Postiglione, Gerard A. 1992. "Implications of modernization for the education of China's 
minorities.” In Education and modernization: The Chinese experience, ed. R. Hayhoe. London: Pergamon Press.

Postiglione, Gerard A. 1995. “National minorities and nationalities policy in China.” In The national question: Nationalism, ethnic conflict, and self-determination in the 20th century, ed. B. Berberoglu. Philadelphia: Temple University Press.

Postiglione, Gerard A. 2000. "National minority regions: Studying school discontinuation.” In The ethnographic eye: An interpretative study of education in China, eds. J. Liu, H. A. Ross and D. P. Kelly. New York: Falmer Press.

Postiglione, Gerard A. 2007. Ethnic minority policy in education: The educational challenge of harmonious multiculturalism. Paper presented at the Beijing Forum: The harmony of civilizations and prosperity for all diversity in the development of human civilization, Beijing, China.

Said, Edward W. 1979. Orientalism. New York: Vintage.

Sautman, Barry. 1998. "Preferential policies for ethnic minorities in China: The case of Xingjiang.” In Nationalism and ethnoregional identities in China, ed. W. Safran. London: Frank Cass.

Shen, Jing Zhe. 2006. Jiaqiangduiqueshaojiatingjiaoyuxueshengde deyushijianyanjiu, cujinxueshenghexiefazhan, [Improving moral education to promote all-round development for Korean students with the lack of family education]. Paper presented at the Korean Chinese Education Forum (1906-2006), Yanbian University, China.

Shin, Gi-wook. 2002 The paradox of Korean globalization, Paper presented at the conference on Social Cohesion and Globalization in Korea, University of British Columbia, Canada. 
Suárez-Orozco, Marcelo. 1991. "Immigrant adaptation to schooling: A Hispanic Case.” In Minority status and schooling: A comparative study of immigrant and involuntary minorities, eds. M. Gibson and J. Ogbu. New York: Garland Press.

Sue, Stanley, and Okazaki, Sumie. 1990. "Asian-American educational achievements: A phenomenon in search of an explanation.” American Psychologist 45(8): 913-920.

Suzuki, Bob H. 1977. "Education and the socialization of Asian Americans: A revisionist analysis of the "model minority" thesis." Amerasia Journal 4(2): 23-51.

Suzuki, Bob H. 1980. "Education and the socialization of Asian Americans: A revisionist analysis of the "model minority" thesis." In Asian-Americans: Social and psychological perspectives, eds. R. Endo, S. Sue and N. N. Wagner. Ben Lomond, CA: Science and Behavior Books.

Suzuki, Bob H. 1989. "Asian Americans as the model minority: Outdoing whites? Or media hype?” Change, November/December: 13-19.

Takagi, Dana Y. 1992. The retreat from race: Asian American admissions and racial politics. New Brunswick, NJ: Rutgers University Press.

Tang, Joyce. 1993. "The career attainment of Caucasian and Asian engineers." Sociological Quarterly 34: 467-96.

Wing, Jean Yonemura. 2007. "Beyond black and white: The model minority myth and the invisibility of Asian American students.” The Urban Review 39(4): 455-487.

Wong, Paul., et al. 1998. “Asian Americans as a model minority: Self-perceptions and perceptions by other racial groups.” Sociological Perspectives 41 (1): 95-118.

Woo, Deborah. 2000. Glass ceilings and Asian Americans: The new face of workplace barriers. Walnut Creek, CA: Altamira Press. 
Xie, Yu, and Goyette, Kimberly A. 2004. A demographic portrait of Asian Americans. Population Reference Bureau and Russell Sage Foundation: Washington, D. C. and New York.

Zhang, Tian Lu, and Huang, Rong Qing. 1996. Zhongguoshaoshuminzurenkou diaochayanjiu, [Demographic studies on China’s minority nationalities]. Beijing: Higher Education Press.

Zhou, Ming Lang. 2000. "Language attitudes of two contrasting ethnic minority nationalities in China: The 'model' Koreans and the 'rebellious' Tibetans." International Journal of the Sociology of Language 146: 1-20.

Zhou, Min, and Gatewood, James V. 2000. "Mapping the terrain: Asian American diversity and the challenges of the twenty-first century.” Asian American Policy Review IX: 5-29.

Zhou, Min, and Kim, Susan S. 2006. “Community forces, social capital, and educational achievement: The case of supplementary education in the Chinese and Korean immigrant communities." Harvard Educational Review 76(1): 1-26. 